Izvorni znanstveni rad

\begin{abstract}
Alma Vančura
avancura@ffos.hr

Faculty of Humanities and Social Sciences

University Josip Juraj Strossmayer, Osijek

Croatia
\end{abstract}

\title{
Speech characteristics as progress indicators in simultaneous interpreting by trainee interpreters
}

\begin{abstract}
Summary
This paper examines speech characteristics of trainee interpreters simultaneously interpreting from English into Croatian during three months of training. It investigates different types of content departures in the form of substitutions, omissions and additions, and their influence on the overall performance in simultaneous interpreting, both on the intertextual and intratextual level. It identifies overall patterns of these departures on the level of the sentence and of individual lexical items, and shows the most typical departures in greater detail by providing a detailed typology for each of them. Phrasing changes most likely signal progress and shift in the trainee's skill from verbosity and literal word-for-word interpreting to condensation and abstraction.
\end{abstract}

Key words: simultaneous interpretation, trainees, progress indicators, speech characteristics, errors 
'They say that nobody is perfect. Then they tell you practice makes perfect. I wish they'd make up their minds.' Wilt Chamberlain

\section{INTRODUCTION}

In the last thirty years, with the development and accessibility of technology that can be used in research, numerous studies have been conducted on simultaneous interpreting (SI) in order to gain a better insight into the process, production and reception of this complex cognitive activity, all for the purpose of improving the quality and understanding the workings of SI. With regard to methodology, studies (Barik, 1975; Altman, 1994; Riccardi, 2002; Schjoldager, 2002 (1995); Bakti, 2009; Gile, 2009; Bogucki, 2010, to name but a few) have concentrated on providing the interested reader access to new revelations that could be used in learning and teaching of SI. Studies have focused on many aspects of SI, but very few (Shlesinger, 1992; Vik-Touvinen, 1995) have provided a detailed analysis of trainees' content and presentation departures typology and observation of these typologies through time which, consequently, can provide an insight into trainees' speech characteristics and possible progress indicators.

\section{THEORETICAL BACKGROUND}

\subsection{Errors, mistakes, departures}

As early as the 1950 s, scholars were interested in analysis of speech errors and disfluencies produced by normal speakers 'as a window into the cognitive processes of speech planning (...) to provide systematic evidence of how conceptual, syntactic, and articulatory processes cope with increased processing load' (Tóth, 2011). Both error and mistake signify a deviation from the expected norm/form and show that the speaker has departed from the usual standard. Corder (1981) distinguished between two types of errors. One type are those errors that can be the result of slips of the tongue, memory lapses, physical states such as tiredness or psychological conditions such as strong emotion, and he called them errors of performance and believed that these should not be called errors but mistakes since they do not reflect a 'defect in our knowledge of our own language' (Corder, 1981: 10). The other type are errors of competence or 'real' errors, and unlike mistakes, which are unsystematic, reflect the learner's acquisition of the second language. Falbo (1998: 110-11) thinks that errors can be observed in a broad sense and puts everything that presents 'violation de la 
cohésion et de la cohérence de TO en TI, et l'équivalence au niveau du contenu et de la forme entre $\mathrm{TO}$ et $\mathrm{TI}^{11}$ into this category.

It has been established that it is fairly common to change one's train of thought, especially if the speech is unprepared, let alone in SI where 'speakers make mistakes, hesitate, halt, repeat parts of the speech and correct themselves. This reveals that the speech is a planned process.' (Horga, 1995: 390). The linearity of SI makes the interpreter constantly predict the incoming information, as well as heavily rely on memory, thus working at high processing capacities. Gile (2009) connects the possible workings of different types of Efforts (Listening and Analysis Effort, the Short-term memory Effort, the Speech production Effort and the Coordination Effort) that the interpreter is engaged in with the Tightrope Hypothesis (Gile, 2009: 182). He claims that interpreters mostly make interpreting failures such as errors or omissions not because of lack of knowledge, but because they constantly work at near saturation level and close to their maximum processing capacities.

As established, even in normal speech, mistakes are a natural part of speech production, let alone in simultaneous interpreting. As such, mistakes should be excluded from the evaluation of the success of the final product. This naturally complicates things, because on the one hand it is hard to discern what could be classified as an error of performance and what as an error of competence, as we would need the same text being interpreted more than once to establish whether the error is systematic or not. On the other hand, we can recognize an 'error' when we hear one (in terms of grammaticality, word choice, etc.). Also, errors can be overt (identifiable) and covert (unidentifiable) errors. Both pose problems, the first are the ones we can hear, because they are mostly errors in grammar or syntactic structure and the second ones can be even graver, because we are not alerted to the error, and yet the error is present (hence the intertextual comparison of texts; see 2.2. and 3.1.). In order to avoid the very disputed term 'error', everything that represents content departures, discontinuities or anything that is different from the source-language text (ST), and not as something that necessarily hinders successful communication and rendition of the text, we will call 'content departures' (CDs).

\subsection{Quality criteria/parameters}

As established, SI is challenging for professionals, let alone for trainees/novices. Nevertheless, both need to be evaluated for their work (the latter specifically if they are doing the activity as a part of a university course). So, the question remains, what

\footnotetext{
${ }^{1}$ A violation of cohesion and consistency between the ST and the TT, and the equivalence in content and form between the ST and the TT (translated by the author).
} 
should be taken into account when evaluating someone's work? There has been extensive research on quality parameters/criteria (Cartelieri, 1983; Pöchhacker, 2002; Kalina, 2005; Venuti, 2008), as well as on aptitude testing for conference interpreting (Moser-Mercer, 1994; Russo, 2014). It was Bühler (1986) and her criteria on quality parameters that laid the foundation for further research, despite the common consensus that quality parameters are somewhat inconsistent and definitely numerous. Quality in interpreting is perceived as a balance between content (grammaticality, accuracy, fidelity, linguistic correctness, style, etc.) and form/presentation (fluency, voice, diction, overall impression, delivery, comprehensibility, etc.). To decide whether the target-language text (TT) has fulfilled the criteria of 'fidelity' and 'completeness', we need intertextual comparison between texts, and the same can be said for 'accuracy'. When it comes to accuracy, already in the 1970's researchers started observing errors and classifying them. It was Barik (1971) who first tried to enumerate various mistakes (errors, omissions, etc.) but never defined under which circumstances they could be assessed as a lack of quality. Gerver (1976: 186) stated that 'both Barik's and Gerver's method of classifying errors are open to objection that the criteria used are purely subjective.'

In the end, the concept of quality is context dependent and it changes together with the norms and the communicative situation, as well as the perspective (i.e. of the sender, receiver of the target-language text, the client, the translator, the researcher (Pöchhacker, 2002)) one takes. When looking at all the possible positions for assessing the quality in SI, the conclusion is that there is no one uniform way in assessment of quality in interpretation. There is huge dependency on the interested party. For this research we have assessed the possible quality of interpreting by assessing it from the position of a researcher (Pöchhacker, 2002) / revisor (Gile, 2009) and observing it from the point of the final product, i.e. rendition of the target text together with the context in which the interpretation is taking place. Finally, we agree that the rendition of the target text should always be observed from the point of skopos theory (Viezzi, 1996; Pöchhacker, 2002; Setton, 2002; Nolan, 2005; Gile, 2009) that is, by the 'function' or 'purpose' of the text and by its communicative value on a projected audience. Kurz (1993), Viezzi (1996), Falbo (1998), Garzone (2002), Pöchhacker (2002), Riccardi (2002), Setton (2002), Viaggio (2002), Nolan (2005), Gile (2009) all favor the situational context and communicative effect of the TT and Gile (2009: 37) thinks that 'for students, the goal should always be to serve communication interests.' 


\subsection{Analysis of errors and content departures on pedagogical grounds}

It looks as if subjectivity is unavoidable in any assessment of SI and yet observation of content and presentation departures from the ST seems to be one of the core criteria in the assessment of interpreting quality. This especially applies to further understanding of the interpreting processes done by trainees and to the establishment of quality assessment parameters (Setton, 2002). Initially, authors were more concentrated on errors than on the functionality of the text. Corder (1981: 1) justified the analysis of errors on pedagogical grounds as 'a good understanding of the nature of error is necessary before a systematic means of eradicating them could be found.' Kopczyncsky (1983) believed that errors are indicative of the language proficiency of students, about the wrong interpreting strategies they use and about the problems one should further explore in language enhancement classes. Altman (1994: 25) shared this opinion in hope that 'an analysis of the most frequent types of errors might make it possible to predict (...) the production of errors by student-interpreters' and Falbo (1998: 107) said 'une classification systématique des erreurs pourrait mener à une explication des causes qui les provoquent' ${ }^{2}$.

\section{THE STUDY}

\subsection{Aims of the study}

This paper will present the analysis of simultaneous interpreting of second-year graduate students of translation studies from the Faculty of Humanities and Social Sciences in Osijek. The investigation will target different levels (grammatical, syntactical and lexical) of interpreting, by analyzing the possible content departures during the interpreting process, and by comparing the speeches in the initial stage (first and second interpreting) and in the final stage (penultimate and last interpreting) during three months of training.

It will focus on the SI done by the trainees, observing it globally, evaluating and comparing both the autonomous text (the final product) and the intertextual level (comparison between the ST and the TT). Finally, the paper will provide some insights into speech characteristics of trainee interpreters.

\footnotetext{
${ }^{2}$ A systematic classification of errors could lead to an explanation of the causes that trigger them (translated by the author).
} 
This paper addresses the following questions:

- What are the main differences between the first/second and the penultimate/final interpreting by trainees, if any?

- What types of content departures are the most/least frequent?

- What are the possible progress indicators?

Based on the previously mentioned research (see 1, 2.2. and 2.3.) we hypothesize that the initial simultaneous interpreting will have more content departures on all levels, more semantic errors and CDs on the level of single lexical unit, and more omissions due to lagging behind and poor understanding of the text. The penultimate/final interpreting will have more CDs on the level of the sentence, and fewer gross semantic errors.

\subsection{Subjects, corpus and methodology}

This paper examines the output of nineteen trainee interpreters (thirteen female, six male) who interpreted various speeches from English into Croatian (mother tongue) during three months of training as a part of a course Introduction to Simultaneous Interpreting. The trainees tested in the present study had never practiced SI before the training. The trainees worked on their own, and could not rely on the help of their 'boothmate' in case of any problems.

They interpreted speeches from the Speech Repository Portal, which is an e-Learning tool available to students of interpreting, teachers and professional conference interpreters working for European Union institutions. The subject matter of all the speeches derived from different fields (economics, agriculture, politics, health, etc.). Videos of the speaker(s) delivering the source language (SL) speech(es) were played to the trainees, who watched them in an interpreter's booth with an audio feed. Their interpreting was recorded with the Cool Edit Pro 2 program, using 96000 sample rate, mono channel 16-bit resolution. The microphone was held at $30 \mathrm{~cm}$ from the speaker's mouth. Approximately 17 hours of recorded material was analyzed.

Each interpreting done by a trainee was listened to by two professionals who assessed the texts in two different ways: a) without comparison to the ST, which was based on the notion that interpreted text (IT) is an 'autonomous text' (Falbo, 2002: 117) and b) with comparison between the ST and the TT, i.e. introducing the intertextual level (Shlesinger, 1997) based on the notion that IT is also a text that depends on the corresponding ST (Falbo, 2002: 117). In order to assess the fidelity, the ST and the TT were compared and coded according to the following scheme (see Figure 1.): CDs were divided into several categories based on the intertextual level of 
analysis; equivalence relations between the ST and the IT (Riccardi, 2002), and further developed through Barik's (1994) and Vančura's (2011) coding schemes.

In the end, quantitative (exact number of each instance was measured) and qualitative (each CD was placed in strategic, negligible or disturbing category (Riccardi, 2002)) analysis was carried out to see the differences between the first/second and the penultimate/last interpreting.

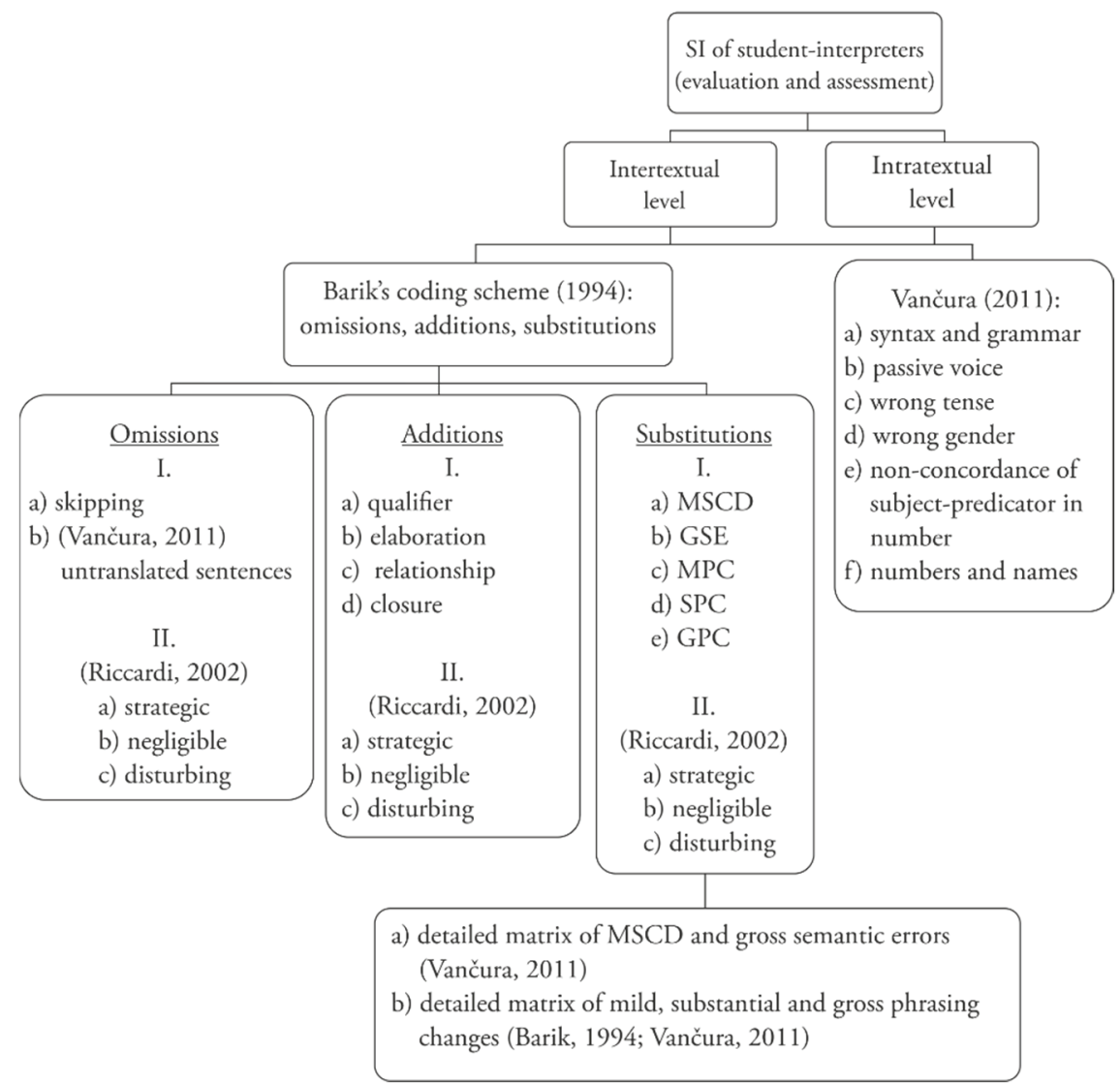

Figure 1. Diagram of the coding scheme

Slika 1. Dijagram - shema kategorizacije

Barik's (1994) categories were further analyzed because simultaneously with the listening of the interpreted text, decisions were made into which of the categories CDs should be placed. On the level of individual lexical items, only two possibilities were present, i.e. either the trainee made a different choice from the ST which was almost 
insignificant in terms of quality (mild semantic content departures), or the choice was poor and presented a grave distortion form the original ST and was placed under gross semantic error (GSE). When it comes to phrasing changes (PC), here the range of different choices trainees made was of a larger extent, so we placed them under three different categories - mild (MPC), substantial (SPC) and gross phrasing changes (GPC). All these categories were further subdivided, but for the lack of space, only those that will be presented in the results section will be explained (for details see Vančura, 2011: 72-79).

Table 1. Matrix of mild semantic content departures and gross semantic errors

Tablica 1. Detaljne kategorije malih promjena te velikih semantičkih pogrešaka

\begin{tabular}{|c|c|}
\hline MSCD / Male promjene & GSE / Velike semantičke pogreške \\
\hline - direct transfer & - direct transfer \\
\hline - borrowing & - borrowing \\
\hline - paraphrase & - paraphrase \\
\hline - similar meaning & - wrong collocation \\
\hline - similar meaning - different style & - wrong collocation - false reference \\
\hline - wrong collocation & - wrong preposition \\
\hline - wrong preposition & - wrong lexeme \\
\hline - wrong lexeme & - wrong lexeme - false reference \\
\hline - wrong lexeme because of false reference & - lexical invention - false reference \\
\hline - wrong preposition - false reference & - wrong connective \\
\hline - lexical invention - false reference & - wrong adverb \\
\hline - wrong case & - false friend \\
\hline - false friend & - wrong number \\
\hline - wrong number & $\begin{array}{l}\text { - misunderstanding because of a } \\
\text { homonym, near homonym or a near } \\
\text { sounding word }\end{array}$ \\
\hline
\end{tabular}

Mild semantic content departures (MSCD) represent departure from the ST, which only slightly distorts the intended meaning. The departure is restricted to the lexical item or expression, and does not affect the rest of the unit of which it is part. The gist is retained and communicative value is not affected. Gross semantic errors significantly changed the sense of what was conveyed by the original message. 
Phrasing changes were analyzed according to Barik's (1994) categorization, and where necessary, some categories were added. Mild phrasing change (MPC), signifies that the trainee does not say the same thing as the source language speaker, but the gist of it is retained and not affected. Substantial phrasing change (SPC) - phrasing is more marked and leads to a difference in meaning, but the overall gist of what is said is not too distorted. Gross phrasing change (GPC), resulting in a considerable difference in meaning.

Table 2. Matrix of mild, substantial and gross phrasing changes

Tablica 2. Kategorije malih, značajnih i velikih rečeničnih promjena

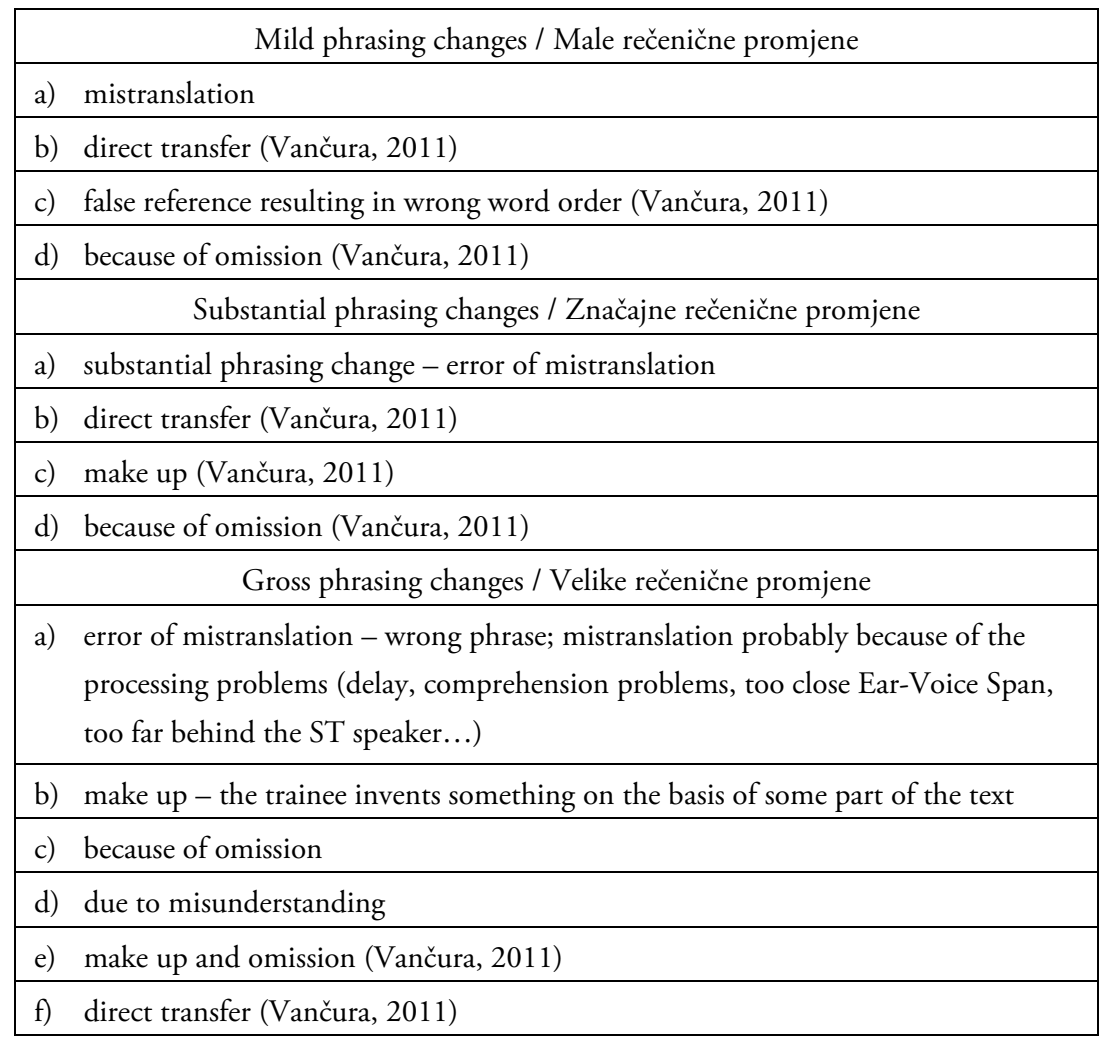

Last but not least, one must take into consideration the neutralization of an error. Precisely, here is where Riccardi's (2002: 24) qualitative division of CDs into strategic, i.e. useful for the global economy of the performance, negligible - those that are imperceptible or disturbing - those liable to alter the sense, proved useful. 


\section{RESULTS}

\subsection{The first/second interpreting - overall results}

The expectations for the overall evaluation of the first two interpretings were not high, even though the trainees had been able to listen to the speeches beforehand and familiarize themselves with the glossary and the topic of the texts. Interestingly enough, some of the students sat in the booth and just started interpreting as if it was the most natural thing for them, something that they had been doing for some time now. This would be along the line of those scholars who claim that interlingual mediation is a natural gift (Harris \& Sherwood, 1978 qtd. in Kalina, 2000: 7). However, recent research has shown that 'the assumption that only gifted individuals may become conference interpreters has gradually given way to a more articulated concept of interpreting aptitude which ranges from holistic assumptions to scientifically sound measurements' (Russo, 2014: 27). First, the cumulative results will be shown and commented on.

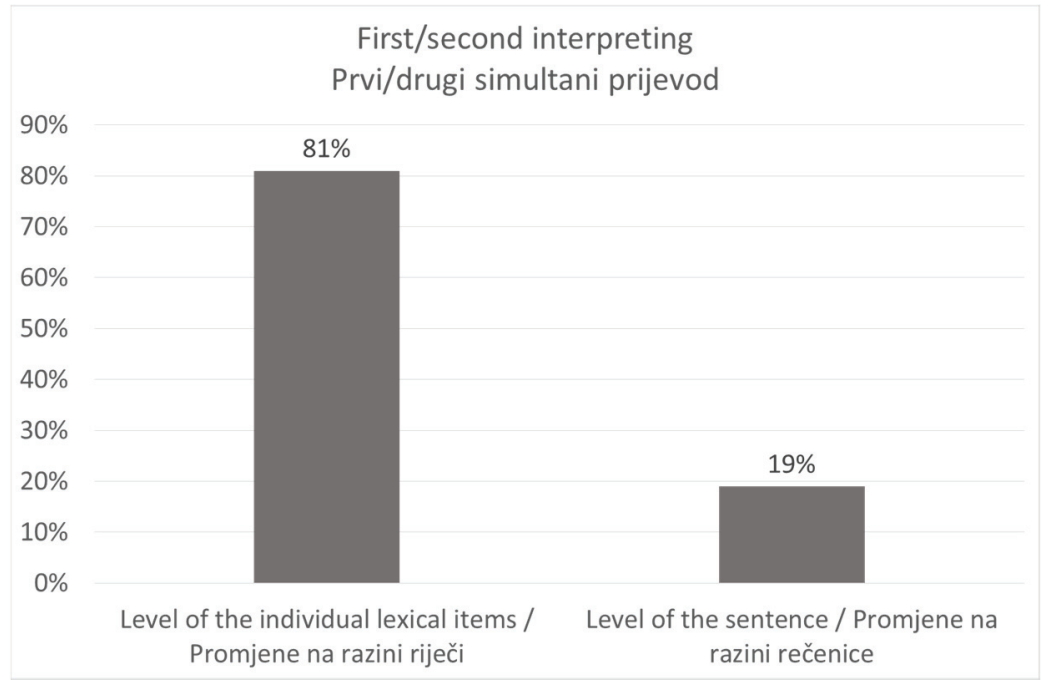

Figure 2. Total sum of the content departures - the level of individual lexical items and the level of the sentence in the first/second interpreting

Slika 2. Ukupan broj promjena na razini riječi i na razini rečenice u prvom i drugom simultanom prijevodu

The figure shows that, in the first/second interpreting, content departures on the level of the individual lexical items account for $81 \%$ of the interpreted material. This can be explained with the trainees' desire to understand, remember and interpret all 
the words that are coming through the headphones. This goes along the lines of Viaggio (1992: 48), who claims that 'the beginner (...) tends to cling to words, not even semantic meaning: as soon as he believes he has grasped a word he spits out the first dictionary equivalent that comes to his fretted mind.' Inevitably, syntax as well as sense gets distorted. The reason for this clinging to words is that, according to Viaggio (1992), beginners start to talk too soon, before they have understood the sense of the message. The trainees in this study behaved similarly, as they were obviously grasping to understand and interpret the incoming message. Different types of content departures the trainees made while doing the interpreting will be presented in the detailed typology.

\subsection{Substitutions}

Substitutions were used by all the trainee interpreters, because there almost never exists one-to-one correspondence between the languages, so that substitution is a normal occurrence in SI. Before providing the examples found in the corpus, what must be stressed is that the assessment of translation and assessment of interpreting are done according to different criteria and that something that seems like a gross error in a written text, can only be a minor one in oral rendition of the text.

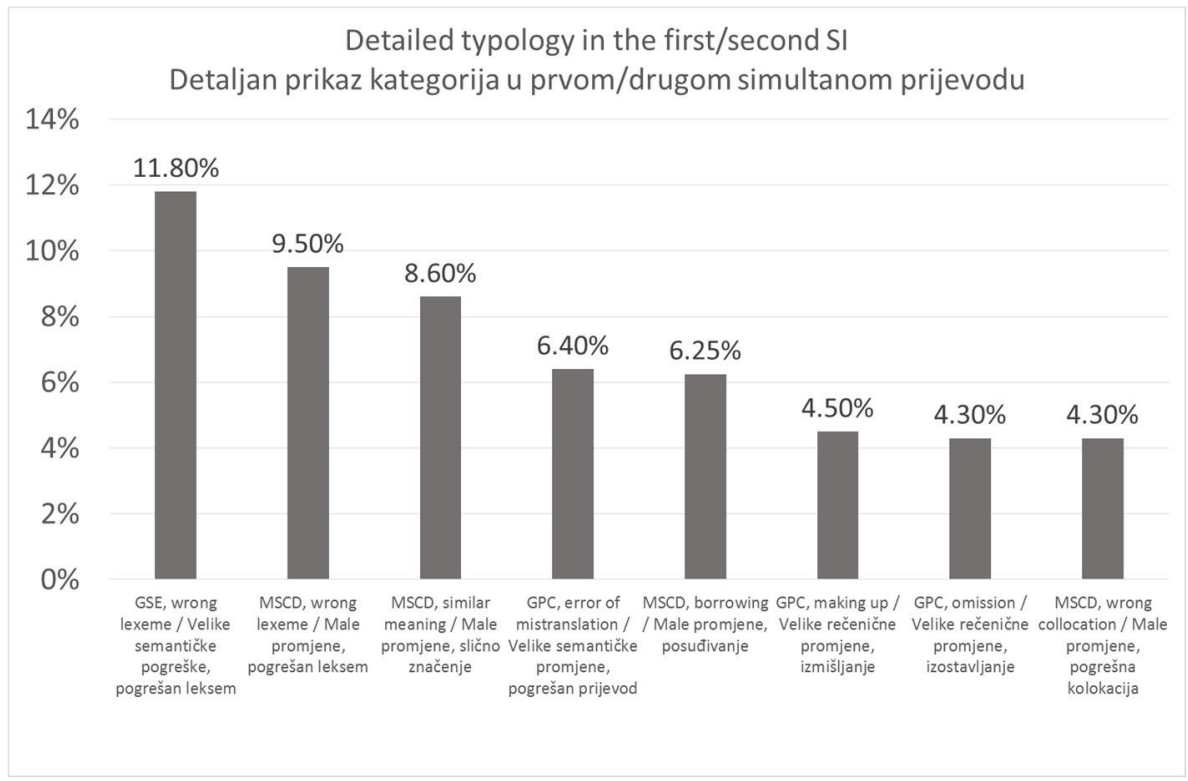

Figure 3. Detailed typology of content departures in the first/second simultaneous interpreting

Slika 3. Detaljan prikaz kategorija u prvom i drugom simultanom prijevodu 
The eight most frequent types of content departures make up for $55.65 \%$ of the total content departures committed by the trainees, out of which $11.8 \%$ make gross semantic errors - wrong lexeme, followed by mild semantic content departures wrong lexeme with $9.5 \%$. MSCDs of similar meaning to the source text are third with 8.6\%. They are followed by gross phrasing changes and MSCDs - borrowing. The 6th, 7th and 8th position is occupied by gross phrasing changes of making up, omission and MSCDs - wrong collocation, with 4.5\%, 4.3\%, and 4.3\% each. The other $44.35 \%$ of departures were not shown in this categorization because there would be too many categories. Each category that was left out was below 20 instances of total occurrences in all of the trainees' interpreting, which attributes each category to less than $4 \%$ of the total sum.

Each category from Figure 3. will be presented in more detail.

Gross semantic error as a result of wrong lexeme:

(1) ...the idea is that the number of producers who would install would be... ${ }^{3}$

...ideja je da broj potrošača koji bi instalirali solarne panele...

...idea is that number consumers that be install solar panels...

...the idea is that the number of consumers who would install solar panels...

(2) ...up to 45 seconds.

...čak do 45 minuta.

...even till 45 minutes.

...even up to 45 minutes.

Numbers have traditionally been perceived and confirmed as being problem triggers in SI due to low predictability and because they burden the processing capacities (Vančura \& Milić, 2015). This is such an example, where the lexeme influences the rendition of the text, showing that the student probably concentrated on the number and used his/her efforts to render it correctly, so no processing capacity was left for the following lexeme.

MSCDs represent 'error or inaccuracy of translation of some lexical item, which only slightly distorts the intended meaning', according to Barik (1994: 128). Category

\footnotetext{
3 The examples are presented as following: 1) first line: source-language text in English 2) second line: target-language text in Croatian rendered by the trainee 3) third line: word-by-word or morpheme-bymorpheme glosses of the target-language text 4) fourth line: translation into English (if necessary, i.e. if the word-by-word translation from the third line is unclear).
} 
of MSCDs (wrong lexeme and similar meaning) cannot be categorized as error and these are only perceived in a cross comparison between the ST and the TT. As with the 'wrong lexeme', category 'similar meaning' signifies that the lexeme that was used has a very close meaning to the one not rendered and would be more precise if it were used, but what was rendered in the TT does not affect the gist of what was being said in the ST. MSCDs as a result of borrowing were quite frequent both in the first/second interpreting as the direction of borrowing from English into Croatian and adaptation to the phonological and morphological system of the target langauge has been established. Therefore, we believe that the high percentage of MSCDs only signal a positive outcome for the trainees since they exhibit the reformulation process widely used by the students.

MSCD as a result of a wrong lexeme:

(3) In the Gospel Jesus Christ enjoins his disciples not to...

U Evandelju Isus Krist govori svojim učenicima...

In Gospel Jesus Christ speaks his disciples...

In the Gospel Jesus Christ speaks to his disciples...

MSCD due to similar meaning:

(4) They are modem, they are powerful, they are equipped with radars.

One su moderne, moćne i opremljene su radarima.

They are modern, mighty and equipped are radars.

They are modern, mighty and equipped with radars.

Gross phrasing errors signify changes that gravely distort the original meaning. Unlike departures that are the result of omission and making up, where one can likely explain why the particular phrasing 'error' occurred, with this category one can only venture to do the same. Had the trainee heard the incoming message and been able to understand it (comprehension), or if s/he had not been lagging too far behind (delay), s/he would have produced a successful TT.

MSCD as a result of borrowing:

(5) ...the most prominent interpreters were...

...najprominentniji tumači su bili...

...the most prominent interpreters were... 
Borrowing signifies a word that originally entered the Croatian language as a loan word from English. Croatian language has two possibilities for this word, one that is phonologically and morphologically different: istaknut, and the other: prominentan that is obviously borrowed and only slightly adapted to Croatian language. The borrowed expression should easily integrate into the TL, both phonologically and morphologically, and the pattern that has been established between the languages and the possibility to just transpose the word to the TT confirms that naturalization is one of the tactics used in SI (Gile, 2009).

Gross phrasing changes due to mistranslation:

(6) ...which granted the Maoris full, exclusive and undisturbed possession of the land...

...Maorima su dana četiri položaja u teritoriju...

...Maoris were given four positions in territory...

...Maoris were given four locations of the territory...

When it comes to first and second interpreting, the initial hypothesis that there would be more semantic departures on the level of single lexical unit was confirmed. Also, besides using a completely wrong word for something in the TT (category of gross semantic errors - wrong lexeme), trainees showed an obvious tendency towards verbosity (Shlesinger, 1992; Viaggio, 1992; Altman, 1994) or excess verbiage (reflected in the category MSCD - wrong lexeme), which is caused 'by failure to lexicalize as one word or idiom a concept which is expressed by several words (a string) in the source language' (Shlesinger, 1992: 124). What trainees at this point have not successfully learned is how to productively use 'associational and expressional fluency' (Gerver, 1989 qtd. in Russo, 2014: 131), i.e. 'the ability to produce words which share a given area of meaning or some other common semantic property and the ability to think rapidly of words, groups of words, or phrases as well as contrast with the production of single words by focusing on the compositional aspects of sentences and on the manipulation of syntactic constructions.'

\subsection{The penultimate/final interpreting - overall results}

After three months of training, the analyzed results showed a general shift in the ratio of content departures on the level of individual lexical items and the level of the sentence. 
The overall results showed the movement towards departures made on the level of the sentence and the content departures within individual lexical items decreased.

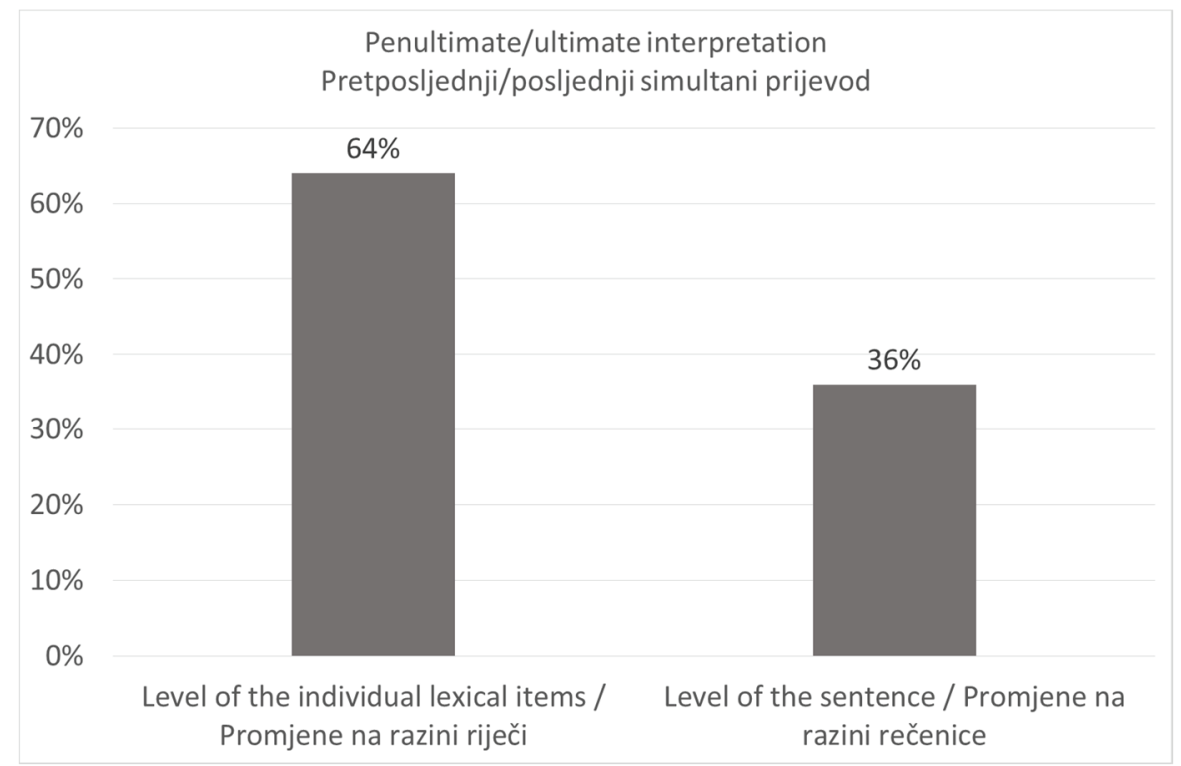

Figure 4. Total sum of the content departures - the level of individual lexical items and the level of the sentence in the penultimate/last interpreting

Slika 4. Ukupan broj promjena na razini riječi $i$ na razini rečenice $u$ pretposljednjem i posljednjem simultanom prijevodu

The trainees made a shift towards content departures made on the level of sentence (a 17\% increase in the latter) when compared to the first/second interpreting. The result shows a positive shift in the students' skills, which can be explained with the fact that more content departures on the level of the sentence signify their attention swerving towards listening to the sentence, or at least a meaningful unit, rather than word after word. General understanding of the sense is the process that is advocated in teaching trainees (Viaggio, 1992), who finds it necessary in order for the trainees to correctly deliver the message. The following table will show detailed content departures typology at the end of the training. 


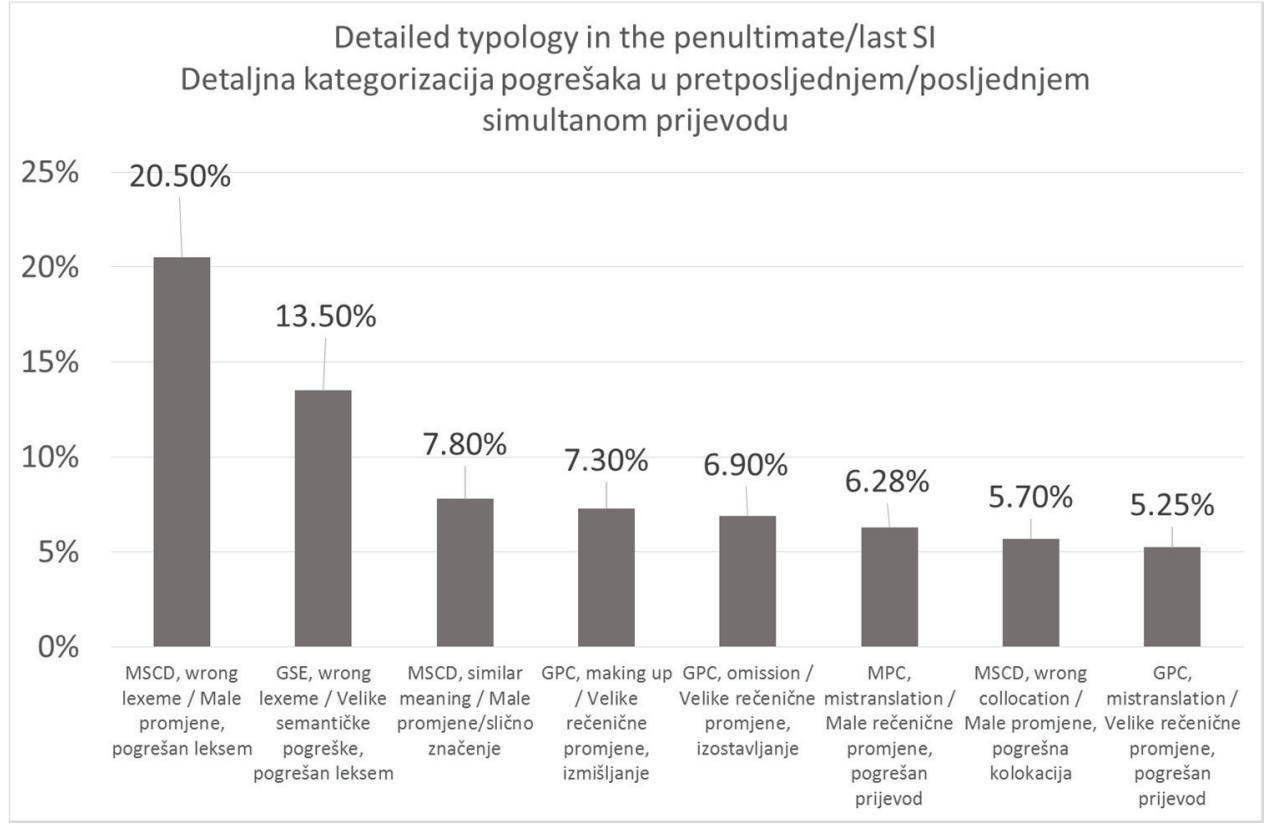

Figure 5. Detailed typology of departures in the penultimate/final interpreting Slika 5. Detaljan prikaz kategorija u pretposljednjem i posljednjem simultanom prijevodu

When comparing the results of the first two and the last two interpretations, we can see the change in positions of some categories. Unlike in the first two, where the highest number of occurrences were those with lexemes that gravely distorted the message in the TT, here they occupy the second position with $13.5 \%$ of all CDs. MSCDs - wrong lexeme and similar meaning - together make $28.3 \%$ of the total occurrences, which goes in hand with the trainees' progress, because they are observed as the interpreter's strategy which s/he chooses under cognitive and time constraints and do not signal any kind of content departures while listening to the interpreting as autonomous text. This is also confirmed in a study by Gerver et al. (1984 qtd. in Russo, 2014), who found that successful synonym production or production of those words that are semantically related, which in our case can be correlated with MSCDs of 'wrong lexeme' and similar meaning, seemed a particularly reliable predictor for aptitude for interpreting. 
Following the MSCDs - similar meaning, there are different types of phrasing changes which stem from 'making up', omission and mistranslation (4th, 5th and 6th position). We believe that these departures signal the trainees' shift towards observing the totality of interpreting, rather than word-for-word interpreting. We must not disregard that some of them are still errors and one might say substantial and gross ones.

What has to be emphasized is the huge percentage of MSCDs ( $46 \%$ in the first/second interpreting, $34 \%$ in the penultimate/final interpreting) that were noted as a part of the interpreting process in this research. We consider them as interpreting tactics and part of the interpreting interlanguage (Selinker, 1972 qtd. in Shlesinger, 1992). This is confirmed by Viezzi (1996: 86) who says that sometimes 'what seems to the external observer as apparently two different (erroneous) lexical solutions when compared what the sender and the translator are saying, actually can be exactly the same'.

Finally, in the initial interpreting, after the overall assessment of each trainee, $39 \%$ of them were assessed to have been using substitutions in a strategic way, $35 \%$ had part strategic and part disturbing substitutions and 26\% used substitutions unsuccessfully and they were assessed as disturbing. The final interpreting offered a different picture, where $59 \%$ of the students were assessed to have been strategically using substitutions, $30 \%$ strategically and disturbing and $11 \%$ of the students had disturbing substitutions.

\subsection{Omissions}

Any kind of interpreting inevitably involves omission of material. Although omissions were previously considered part of 'unsuccessful' interpreting and were even measured in terms of the amount of material omitted (Barik, 1994), today's viewpoint (Stenzl, 1983 qtd. in Kurz, 1993; Viezzi, 1996; Garzone, 2002; Gile, 2009 among others) is that omissions are a normal part of the students' and professionals' tactics in interpreting. In order to try and answer that question, instead of Barik's 1975 study, whose results showed that students omit $22 \%$ of the material when translating from a weak into a dominant language, the answer should be given according to Riccardi's (2002) qualitative description of modifications in the TT. 
Table 3. Omissions in the trainees' interpreting - qualitative categorization

Tablica 3. Izostavljanja pri simultanom prevođenju početnika - kvalitativna kategorizacija

\begin{tabular}{|l|c|c|}
\cline { 2 - 3 } \multicolumn{1}{c|}{} & $\begin{array}{c}\text { First/second interpreting / } \\
\text { Prvi/drugi prijevod }\end{array}$ & $\begin{array}{c}\text { Penultimate/final } \\
\text { interpreting / } \\
\text { Pretposljednji/posljednji prijevod }\end{array}$ \\
\hline Negligible / Nerazumljivo & $50 \%$ & $41 \%$ \\
\hline Strategic / Strateški & $14 \%$ & $40 \%$ \\
\hline Disturbing / Ometajuće & $21 \%$ & $13 \%$ \\
\hline $\begin{array}{l}\text { Strategic/disturbing / Strateški- } \\
\text { ometajuće }\end{array}$ & $15 \%$ & $6 \%$ \\
\hline
\end{tabular}

The results in the table are the results of the qualitative categorization of all omissions made by the students, which involve not only skipping omissions, but omissions of the sentences that were not interpreted and were vital for the further understanding and following of the text (intertextual observation). Also, included are the sentences that the students started to interpret and then stopped in the middle of the interpreting (intratextual observation). Most of the trainees' omissions in the first/second interpreting were negligible (50\%), with an equal distribution of strategic, disturbing and those that were both strategic and disturbing covering the remaining $50 \%$ with $14 \%, 21 \%$, and $15 \%$ respectively. In the final interpreting, $41 \%$ of the omissions were considered negligible, $40 \%$ strategic, and $13 \%$ disturbing ones. In the last place, with $6 \%$, were omissions that were at some point in the interpreting assessed as strategic and in some as disturbing (in the same sentence, the student omitted a part that had zero value for the content understanding and then later omitted a part that was vital for the TT understanding; the first part, therefore, was placed under negligible omission and second part under disturbing). What can be noticed in the comparison between the first/second and the penultimate/final interpreting is the huge rise of strategic omissions, which signal the acquisition of a skill comprising of listening in order to interpret things that are of importance and not to stick to wordfor-word interpreting.

\subsubsection{Skipping omissions}

Barik's 1975 study showed that approximately 49\% of the omitted material (marked $\phi$ )consisted of the skipping type, while the other half consisted of the 
comprehension $(20 \%)$ or delay (27\%) type of omissions. The skipping omissions that were analyzed mainly functioned as a strategic tool to unburden the saturation of the short-term memory and their omission did not grossly hinder the fidelity of interpreting. The following are the examples of skipping omissions done by the trainees.

(7) ...I stayed up to watch his inaugural speech...

...gledala sam njegov $\phi$ govor...

...watched was his $\phi$ speech...

...I watched his $\phi$ speech...

(8) It's a company that was founded by the British inventor James Dyson.

To je tvrtka koja je osnovana od britanskog $\phi$ Britanca Jamesa Dysona.

It is company that was founded by British $\phi$ Briton James Dyson.

It is a company that was founded by the British $\phi$ Briton James Dyson.

\subsubsection{Untranslated sentences}

In a cross comparison of the texts, some of the sentences from the ST were not rendered in the TT even though their rendition was crucial for the understanding of the TT. In the overall assessment, $64 \%$ of the cases were evaluated as either negligible or strategic (first two) and $81 \%$ (last two), which signifies that the omissions did not influence the total quality of the interpreting, especially at the end of the training.

(9) It wants to reduce the overcapacity in the industry by giving fishermen money. This money is in exchange for scraping vessels, taking them out of use. More money will be available to retrain the fishermen who lose their jobs.

Žele smanjiti preveliki kapacitet $u$ industriji. $\phi$ Više novca će biti usmjereno na ribare koji su izgubili svoje poslove.

Want decrease too big capacity in industry. $\phi$ More money be will directed on fishermen who are lost their jobs.

They want to reduce the overcapacity in the industry. $\phi$ More money will be directed towards the fishermen who lost their jobs.

The student did not interpret the section which mentions the money, so when we hear the next sentence it doesn't make sense. 
Most of the skipping omissions and untranslated sentences are unconsciously done by the trainee interpreters, because, as Gile (2009: 210) claims, 'interpreters may miss information without noticing it because they did not have enough processing capacity available for the Listening and Analysis Effort when the speech segment carrying it was being uttered. They may also omit it because it disappears from shortterm memory' or because they did not understand something or did not know how to interpret it.

In a study conducted to identify how student and professional interpreters go about the task of interpreting, Gran (1998) concluded that both professional and student interpreters resorted to omission to the same degree in the task of reformulating the incoming speech in a language combination which requires a great deal of abstracting and compressing, although the latter showed a greater tendency to leave out entire relative propositions.

To conclude, omission of material occurs frequently in interpreting by trainees, and we can notice it especially when we compare the ST and the TT. At this level of observation, it is still a bit presumptuous to call it a 'tactic', since it usually stems out of pure necessity and inability to process the incoming material. Nonetheless, Gile (2009) confirms that interpreters favor tactics that require little time and processing capacity, such as omission, naturalization and approximate repetition, over explanation, paraphrasing and informing delegates of the problem. Very similar 'tactics' were subconsciously used by trainees. Only two trainees, whose speech rate is very fast and are very fluent speakers, decided to opt for a solution where they managed to explain words that required paraphrase, because the interpreted word did not have its counterpart in Croatian. The rendition of the material by the trainees showed that many of the content departures committed in all interpreting are classified as phrasing changes due to omission.

\subsection{Additions}

Gerver ([1969] 2002) found that interpreters monitor what they say not only because they tend to correct substitutions in the TT, but also because they tend to improve or change already acceptable translations. This study showed a similar tendency, because most of the additions that were done by the trainees were based on additions of synonyms, i.e. additions of lexemes to the already existing, acceptable ones or because the students felt the need to further explain an already interpreted lexeme. Altman 
(1994), Gran (1998), Shlesinger (1992) and Viaggio (1992) found that verbosity or excess verbiage, with or without redundant information, is part of interlanguage.

\subsubsection{Elaboration addition}

Elaboration addition includes elaboration of the already existing lexeme or other straight addition to the text. This type of addition was further divided into elaborations that are achieved through the addition of a synonym; those that included an explanation in the form of a paraphrase and those where the trainees added another lexical item which turned to be erroneous. All elaboration additions serve to provide a term or a phrase which the trainee considers to be more appropriate than the one previously rendered.

\subsubsection{Elaboration - synonym}

(10) ...to make these clothes more complex and resplendent.

...da naprave ovu odjeću složenijom i sjajnijom, blještavijom. ...to make these clothes more complex and shinier, more resplendent.

\subsubsection{Elaboration - explanation through paraphrase or individual lexical item}

(11) We tend to get the job not finished. This is worrying.

Vrlo često ne dovršavamo posao, ono što smo započeli, a to je zabrinjavajuće. Very often not finished job, that what were started, and this is worrying.

Very often we do not get the job finished, what we started, and this is worrying.

The percentage of this type of additions rose from $16 \%$ in the first/second interpreting to $27 \%$ of the total number of additions in the penultimate/final interpreting. This may signal that learning how to successfully listen and process the ST leaves the trainees with more time to add more material to the TT.

\subsubsection{Relationship addition}

This is addition of a connective or other material which results in a relationship of elements or of sentences not present in the original. The rise from $6 \%$ in the first/second interpreting to $18 \%$ in the penultimate/final interpreting possibly shows 
the students' tendency to become less dependent on the ST in terms of literalness, as well as their capacity to connect sentences in a way not present in the original.

(12) ...unemployment was rising, and as people found themselves out of a job, gave them perhaps a little bit too much time to be able to sit and think and ask difficult and awkward questions about the whole point of the universe, life and our existence.

...nezaposlenost je rasla, a ljudi su imali previše vremena kako bi sjedili $i$ razmišljali o smislu života $i$ naše egzistencije.

...unemployment was rising, and people were having too much time just to be able to sit and think about meaning of life and our existence.

\subsubsection{Closure addition}

This addition accompanies rephrasing, omission or misinterpreting on the part of the interpreter and serves to give 'closure' to a sentence unit, without adding anything substantial to the sentence. This type of addition was rarely used by studentinterpreters both at the beginning (9\%) and at the end of the training $(6 \%)$, which signifies that other tactics were preferred.

(13) ....and doctors are not keen to prescribe sleeping pills. $\phi$ As constant activity is deemed to be the ideal situation, most Japanese would refuse to take a product which might reduce their alertness at work...

... a liječnici nisu za to da im se propisuju tablete za spavanje. Zato Japanci ne žele uzimati proizvode koji bi mogli utjecati na njihov rad...

... and doctors are against prescribing sleeping pills. Therefore, Japanese do not want to take products which might influence their work...

The student omits the clause and connects what follows with the one where the doctors are not keen on prescribing the sleeping pills in order to make some kind of conclusion.

The study showed that slightly more than a half of trainees favor additions as a common tactic, since $54 \%$ of them used additions in both their first and final interpreting and $46 \%$ did not. This shows that some of the students were not over capacitated with the incoming material, since adding even more material requires significant cognitive strain.

Many of the content departures were the result of a linguistic interference of the ST, which is reflected in lexical (borrowing, wrong lexemes because of false reference, 
direct transfer) and syntactic choices (wrong prepositions, wrong word order, nonconcordance of subject-verb in number, passive voice, etc.). The reason could be that trainees, who are at the beginning of their training, need a lot of phonological, lexical, syntactic or semantic elements to produce their TT output. Their semantic interpreting is often unrelated to the context, which is reflected in various (mild, substantial or gross) mistranslations on the level of the sentence. As the time passed, trainees were able to better anticipate and render the text by integrating linguistic and extra-linguistic elements. Still, the results in the final interpreting show that restructuring of the word-order of the ST sentence into a suitable word-order of the TT sentence was not achieved completely. Trainees tended to keep the same wordorder in Croatian as it was in English.

\section{CONCLUSION}

After three months of training, the results showed a general shift in the ratio of content departures on the level of individual lexical items and the level of the sentence. The overall results showed a movement towards departures committed on the level of the sentence and the content departures of individual lexical items decreased by $17 \%$. The fact that more departures were committed on the level of the sentence signifies a shift in the learning process, i.e. one being oriented on the rendition of the sense rather than literal word-for-word translation, and this can be interpreted as one of the major progress indicators. Amateur interpreters use word-for-word interpreting, while more skilled and experienced interpreters are more attuned to the semantic meaning of the TT and all other levels of interpreting to which the beginners are not. Moser-Mercer et al. (2000: 109) confirm that trainees 'tend to treat each utterance/sentence in a more isolated manner and fail to establish discourse links, while expert interpreters display better organization with more associative connections and more domain connections.' The same can be true of the trainees in this paper. They focused on the unknown and got stuck. They tend to favor 'micro-contextual plans' (Barik, 2002: 110) rather than focusing on the global picture of the ST. The first/second interpreting went along these findings, whereas the final ones showed a general movement towards phrasing changes and departure from literalness.

Trainees used various kinds of reformulations of the ST material to produce the TT. What is of interest is the strategic view of the substitutions. A general shift toward strategic usage of substitutions can be noticed. Subjects generally used reformulations 
of a mild type by changing the word from the ST into the one that was similar or a close equivalent in the target language. This is in concordance with Gran's (1998: 155) findings where she confirms that 'the most commonly used substitution procedure adopted was generalization, whereby a sequence of nouns is replaced by one general term or detailed descriptions are greatly simplified.' This is a tactic that is favored by Gile (2009: 206) who proposes a reformulation of speech segments in which a particular lexeme is substituted with a more superordinate lexeme, 'or by constructing a more general segment in the case of the whole clause or sentence.'

Trainees mostly made errors in terms of wrong lexemes, even though they were asked to prepare glossaries beforehand. It shows that processing efforts were over capacitated, which led to comprehension and delay problems, eventually ending in the use of an erroneous lexeme or longer unit of TT. Other popular 'tactics' included phrasing changes by using omission and making up on the basis of some material in the ST or the combination of the two. Gran (1998: 156) confirms that one of the most common simplification strategies of students in her study was 'the fusion of two phrases through the selection of information.'

Omissions were part of the trainees' coping tactics. Pragmatically, some interpreting was rated as containing disturbing errors, since it contained sentences that were omitted and were crucial later for following the message. Mostly they were the result of saturation of the Listening and Analysis Effort (Gile, 2009). Since all the Efforts are mutually connected, saturation of listening and analysis causes slowing down of production. Production results in delay, which in turn overloads the Memory Effort. Final result is inevitably a loss of information. Still, most of the omitted material was categorized as either containing a negligible error (50\% initial two, $41 \%$ in the final two) or a strategic changes ( $14 \%$ initial two; $40 \%$ final two), because interpreting involves loss and it is the sense that the trainees mostly successfully rendered.

As this paper shows, SI is a complex activity that can be observed from various standpoints. Most authors agree that 'function' or 'purpose' of the text and its communicative value are indispensable for defining quality in interpreting. The starting point still lies in faithful rendition of the TT. On the other hand, there is a paradox at work if we consider that certain types of errors signal progress, or to be more precise, that phrasing changes (content departures on the level of the sentence), especially gross phrasing changes can serve as a general indicator of progress. In the analyzed corpus, the phrasing changes such as gross phrasing changes of omission and 
making up, increased over time, and thus signaled use of condensing and abstracting, which is a characteristic of professional interpreters. On the level of individual lexical item, borrowing can serve as another progress indicator. As mentioned earlier (cf. 2.1.), Efforts in simultaneous interpreting are very often working at a near saturation level. Good management of the Efforts is signaled by the absence of borrowed items, because the fewer of them there are, the more processing time, is believed, the interpreter has (otherwise s/he would use a borrowed item to save time). Finally, it is a shift from disturbing to strategic use of the substitutions in the TT that signal progress of an individual. To conclude, with practice and proper guidance, successful rendition of the TT in simultaneous mode is not an unattainable goal, but a trainee's reality.

Last but not least, some comments about limitations of the study will be discussed. The paper described characteristics of a rather short time-span and these progress indicators apply to a period of three-months, which, most would agree, is probably a short period to make firm conclusions. Some follow-up after a year or so would probably give new insights and revelations into this matter. As for the error count, Pöchhacker (2004: 188) claims that 'the use of error counts is notoriously problematic' because it is dependent on many factors, such as lexical variability of interpreter's output, the information values of individual text components, the variability of error rating between different assessors and the impact of norms and expectations, all of which significantly alter the final result. We cannot disregard the fact that the processes in the trainees' mind are still in the field of guessing. All the authors who have dealt with any kind of assessment concede that their classification is subjective and this study is no exception. It seems that subjectivity is unavoidable in any assessment of SI and yet error count, or to be more precise observation of content and presentation departures from the ST, seem to be one of the core criteria in the assessment of interpreting quality. The content departures together with error count served to give answers to the most common types of content departures and errors made when interpreting from English into Croatian. All the research that has been done on the subject, including the present paper which tries to encompass not only errors but the totality of content departures, serves to shed some more light on the process of SI, hoping that it will contribute to the overall understanding of the process of SI. 


\section{REFERENCES}

Altman, J. (1994). Error analysis in the teaching of simultaneous interpreting: A pilot study. In S. Lambert \& B. Moser-Mercer (eds.), Bridging the Gap, Empirical Research in Simultaneous Interpreting, 25-38. Amsterdam/Philadelphia: John Benjamins Publishing Company.

Bakti, M. (2009). Speech disfluencies in simultaneous interpreting. Translation and the transformation of identities. Selected Papers of the CETRA Research Seminar in Translation Studies 2008. (ed. D. De Crom), 1-17.

Barik, H. C. (1971). A description of various types of omissions, additions and errors of translation encountered in simultaneous interpreting. Meta 16, 4, 199-210.

Barik, H. C. (1994). A description of various types of omissions, additions and errors of translation encountered in simultaneous interpreting. In S. Lambert \& B. Moser-Mercer (eds.), Bridging the Gap, Empirical Research in Simultaneous Interpreting, 121-139. Amsterdam/Philadelphia: John Benjamins Publishing Company.

Barik, H. C. (2002 [original 1975]). Simultaneous interpreting: Qualitative and linguistic data. In F. Pöchacker \& M. Shlesinger (eds.), The Interpreting Studies Reader, 78-91. London/New York: Routledge.

Bogucki, L. (2010). Teaching Translation and Interpreting. Challenges and Practices. Newcastle upon Tyne: Cambridge Scholars Publishing.

Bühler, H. (1986). Linguistic (semantic) and extra-linguistic (pragmatic) criteria for the evaluation of conference interpreting and interpreters. Multilingua 5, 4, 231235.

Cartelieri, C. (1983). The inescapable dilemma. Quality and/or quantity in interpreting. Babel 29, 4, 209-213.

Corder, S. P. (1981). Error Analysis and Interlanguage. Great Britain: Oxford University Press.

Falbo, C. (1998). Analyse des erreurs en interprétation simultanée. The Interpreters' Newsletter 8, 107-120.

Falbo, C. (2002). Error analysis: A research tool. In G. Garzone, P. Mead \& M. Viezzi (eds.), Perspectives on Interpreting, 111-127. Bologna: Biblioteca della Scuola Superiore di Lingue Moderne per Interpreti e Traduttori.

Garzone, G. (2002). Quality and norms in interpreting. In G. Garzone \& M. Viezzi (eds.), Interpreting in the 21st Century, Challenges and Opportunities. Selected 
Papers from the 1st Forli Conference on Interpreting Studies, 9-11 November 2000. 107-120. Amsterdam/Philadelphia: John Benjamins Publishing Company.

Gerver, D. (1976). Empirical studies of simultaneous interpreting: A review and a model. In R. W. Brislin (ed.), Translation: Applications and Research, 165-207. New York: Gardner Press.

Gerver, D. (2002 [original 1969]). The effects of source language presentation rate on the performance of simultaneous conference interpreters. In F. Pöchacker \& M. Shlesinger (eds.), The Interpreting Studies Reader, 52-67. London/New York: Routledge.

Gile, D. (2009). Basic Concepts for Interpreter and Translator Training, revised edition. Amsterdam/Philadelphia: John Benjamins Publishing Company.

Gran, L. (1998). In-training development of interpreting strategies and creativity. In A. Beylard-Ozeroff, J. Kralova \& B. Moser-Mercer (eds.), Translators' Strategies and Creativity, 145-162. Amsterdam/Philadelphia: John Benjamins Publishing Company.

Horga, D. (1995). Osobitosti govora simultanog prijevoda. Prevodenje - suvremena strujanja i tendencije: zbornik radova (eds. J. Mihaljević Djigunović \& $\mathrm{N}$. Pintarić), 385-394.

Kalina, S. (2000). Interpreting competences as a basis and a goal for teaching. The Interpreters' Newsletter 10, 1-32.

Kalina, S. (2005). Quality assurance for interpreting processes. Meta: journal des traducteurs / Meta: Translators' Journal 50, 2, 768-784.

Kopczynsky, A. (1983). Deviance in conference interpreting. In A. Kopczynski, A. Hanftwurcel, E. Karska \& L. Rywin (eds.), The Mission of the Translator Today and Tomorrow. Proceedings of the 9th World Congress of the International Federation of Translators, 399-404. Warsaw: Polska Agencja Interpress.

Kurz, I. (1993). Conference interpreting: Expectations of different user groups. The Interpreters' Newsletter 5, 13-21.

Moser-Mercer, B. (1994). Aptitude testing for conference interpreting. In S. Lambert \& B. Moser-Mercer (eds.), Bridging the Gap, Empirical Research in Simultaneous Interpreting, 57-68. Amsterdam/Philadelphia: John Benjamins Publishing Company.

Moser-Mercer, B., Frauenfelder, U. H., Casado, B., Künzli, A. (2000). Searching to define expertise in interpreting. In B. Englund Dimitrova \& K. Hyltenstam (eds.), Language Processing and Simultaneous Interpreting, Interdisciplinary 
perspectives, 107-132. Amsterdam/Philadelphia: John Benjamins Publishing Company.

Nolan, J. (2005). Interpretation: Techniques and Exercises. Great Britain: Cromwell Press Ltd.

Pöchhacker, F. (2002). Researching interpreting quality. In G. Garzone \& M. Viezzi (eds.), Interpreting in the 21st Century, Challenges and Opportunities. Selected Papers from the 1st Forli Conference on Interpreting Studies, 9-11 November 2000, 95-106. Amsterdam/Philadelphia: John Benjamins Publishing Company.

Pöchhacker, F. (2004). Introducing Interpreting Studies. London: Routledge.

Riccardi, A. (2002). Interpreting research: Descriptive aspects and methodological proposals. In G. Garzone \& M. Viezzi (eds.), Interpreting in the 21st Century, Challenges and Opportunities. Selected Papers from the 1st Forli Conference on Interpreting Studies, 9-11 November 2000, 15-28. Amsterdam/Philadelphia: John Benjamins Publishing Company.

Russo, M. (2014). Aptitude testing over the years. In F. Pöchhacker \& M. Liu (eds.), Aptitude for Interpreting, 7-32. Amsterdam/Philadelphia: John Benjamins Publishing Company.

Schjoldager, A. (2002 [original 1995]). An exploratory study of translational norms in simultaneous interpreting. In F. Pöchacker \& M. Shlesinger (eds.), The Interpreting Studies Reader, 300-311. London/New York: Routledge.

Setton, R. (2002). A methodology for the analysis of interpreting corpora. In G. Garzone \& M. Viezzi (eds.), Interpreting in the 21st Century, Challenges and Opportunities. Selected Papers from the 1st Forli Conference on Interpreting Studies, 9-11 November 2000, 29-46. Amsterdam/Philadelphia: John Benjamins Publishing Company.

Shlesinger, M. (1992). Lexicalization in translation: An empirical study of student's progress. In Dollerup \& A. Loddegaard (eds.), Teaching Translation and Interpreting, Training, Talent and Experience. Papers from the First Language International Conference Elsinore, Denmark, 31 May - 2 June 1991, 123-128. Amsterdam/Philadelphia: John Benjamins Publishing Company.

Shlesinger, M. (1997). Quality in simultaneous interpreting. In Y. Gambier, D. Gile \& C. Taylor (eds.), Conference Interpreting: Current Trends in Research, 123-131. Amsterdam/Philadelphia: John Benjamins Publishing Company. 
Toth, A. (2011). Speech Disfluencies in Simultaneous Interpreting: A Mirror on Cognitive Processes, http://www.skase.sk/Volumes/JTI06/pdf_doc/03.pdf [accessed 3rd April 2017].

Vančura, A. (2011). Characteristics, Quality Indicators and Assessment Criteria of Simultaneous Interpreting by Student-Interpreters: Implications for Interpreting Theory and Teaching Practice (unpublished doctoral dissertation). Osijek: Faculty of Humanities and Social Sciences, University of J.J. Strossmayer.

Vančura, A., Milić, G. (2015). Simultaneous interpreting of numbers: Cognitivelinguistic approach or how to be on cloud nine. In K. Cergol Kovačević \& S. L. Udier (eds.), Multidisciplinairy Approaches to Mulitilingualism. Proceedings from the CALS conference 2014, 281-302. Frankfurt am Main: Peter Lang Edition.

Venuti, L. (2008). The Translator's Invisibility: A History of Translation. London/New York: Routledge.

Viaggio, S. (1992). Teaching beginners to shut up and listen. The Interpreters' Newsletter 4, 45-58.

Viaggio, S. (2002). The quest for optimal relevance: The need to equip students with a pragmatic compass. In G. Garzone \& M. Viezzi (eds.), Interpreting in the 21st Century, Challenges and Opportunities. Selected Papers from the 1st Forli Conference on Interpreting Studies, 9-11 November 2000, 229-244. Amsterdam/Philadelphia: John Benjamins Publishing Company.

Viezzi, M. (1996). Aspetti della Qualità in Interpretazione. Triest: Scuola Superiore di Lingue Moderne per Interpreti e Traduttori, Université degli Studi di Trieste.

Vik-Tuovinen, G.-V. (1995). Progress in simultaneous interpreting - an evaluation of the development of four students. Hermes. Journal of Linguistic 14, 55-64. 


\title{
Alma Vančura \\ avancura@ffos.hr \\ Filozofski fakultet Sveučilišta Josipa Jurja Strossmayera u Osijeku \\ Hrvatska \\ Karakteristike govora prevoditelja početnika pri simultanom prevođenju kao mogući pokazatelj napretka
}

\begin{abstract}
Sažetak
Ovaj se rad bavi karakteristikama govora simultanog prijevoda prevoditelja početnika tijekom nekoliko mjeseci. Njihovi simultani prijevodi su snimljeni i analizirani pomoću intra- i intertekstualne analize kako bi se utvrdila kvaliteta prijevoda te karakteristike govora tijekom simultanog prevođenja. Snimka je prvo poslušana bez usporedbe, a zatim u usporedbi $s$ originalom. Pomoću detaljne matrice razne su promjene svrstane u kategorije te su uspoređeni početni i finalni prijevodi kako bi se utvrdili mogući pokazatelji napretka. Rad istražuje različite tipove promjena teksta u formi preoblikovanja, izostavljanja i/ili dodavanja na razini riječi i rečenice te prikazuje detaljnu tipologiju određenih kategorija kako bi se dobio uvid u najtipičnije promjene i pogreške koje se javljaju kod prevoditelja početnika. Početna je ideja rada bila da detaljna tipologija promjena i pogrešaka posluži za utvrđivanje mogućih kriterija procjene kvalitete simultanog prijevoda, da se ustanove pokazatelji napretka te da se uočeno može iskoristiti za eventualne nastavne smjernice.

Želimo ukazati na jedan od mogućih pokazatelja napretka kod početnika, a to je prelazak od doslovnog prevođenja riječ po riječ i pretjerane gorljivosti do prevođenja smisla, čak i ako takvo prevođenje uključuje značajne rečenične pogreške. Ovaj rad također želi naglasiti da se brojanje "pogrešaka", točnije različitih vrsta promjena, treba promatrati kroz prizmu neutralizacije pogreške (Riccardi, 2002) pa su tako sve promjene kvalitativno promatrane kao strateške, zanemarive ili ometajuće. Pomak od ometajućih prema strateškim promjenama također signalizira napredak prevoditelja početnika. Najčešće promjene koje su radili prevoditelji početnici na kraju obuke bile su: mala semantička promjena nastala zbog pogrešnog leksema ili zbog semantički bliskog značenja, velika semantička pogreška zbog pogrešnog leksema, velika rečenična izmjena zbog izmišljanja na temelju nekog dijela teksta ili zbog pogrešnog prijevoda te značajne i male rečenične izmjene nastale zbog izostavljanja.
\end{abstract}

Ključne riječi: simultano prevođenje, studenti, pokazatelji napretka, govorne karakteristike, pogreške 